\title{
Improvement Suggestions
}

This final Chapter makes suggestions for the enhancement of arbitrator independence and impartiality (and their perception) under the ICsid Convention. Proposals for institutional reforms are complemented by practical suggestions on how specific conflict situations should be dealt with, in order to safeguard the parties' right to an open-minded, rational, and objective evaluation of their claims. Together, the suggestions intend to ensure a predictable standard of independence and impartiality, and its effective enforcement. A short description of how these recommendations can be implemented rounds off the Chapter.

\section{Institutional Reforms}

The following suggestions are based on the realization that certain reforms which transcend the mere clarification of the threshold for arbitrator challenges are needed, in order to effectively improve the perception of ICSID arbitrators' independence and impartiality, and of the entire system's legitimacy. The reforms proposed hereinafter are significantly more conservative than the advances made by other scholars, or by the European Union in the context of CETA and TTIP, as analyzed in the previous Chapter. They focus on three main goals: First, on ensuring that the views of both party-appointed arbitrators are effectively included in the deliberations of the arbitral tribunal; second, on reducing the number of challenges and avoiding particularly problematic conflicts of interest from the outset, before the proceeding even begins; and third, on avoiding that disqualification decisions appear illegitimate, because those who make them are perceived to be insufficiently independent and impartial to do so.

\subsection{Appointment of the Chairperson from a Roster}

As previously stated, tensions between the parties' autonomy to appoint their arbitrators and the requirement of independence and impartiality must be resolved in favor of the latter. ${ }^{1098}$ For this purpose, this Chapter makes a proposal

1098 ICSID Convention art. 40, para. 2 in connection with art. 14, para. 1.

(C) MARIA NICOLE CLEIS, 2017 | DOI 10.1163/9789004341487_007

This is an open access chapter distributed under the terms of the CC-BY-NC Micenseficole Cleis - 9789004341487 
for clear, quantitative rules on conflicts of interest, and suggests procedural modifications of arbitrator appointments and challenges. These proposals aim to safeguard the parties' right to decision-makers who will evaluate their claims open-mindedly, rationally, and objectively.

Realistically, however, it is impossible to entirely avoid the participation of pre-conceived arbitrators on tribunals. Pre-conceptions might not rise to the level of bias, but be more general and abstract. An appointing party may appoint a like-minded arbitrator, who is nevertheless able to approach the specific case open-mindedly, and to analyze the relevant facts objectively and rationally. If the views of the arbitrator appointed by the opponent are just as aligned with the views of her or his appointing party (but the adjudicator's independence and impartiality is guaranteed), a certain antagonism or opposition between the party-appointed arbitrators (on a very abstract and professional level) is inevitable.

Furthermore, requests for the disqualification of dependent or partial arbitrators might fail. The lowering of the threshold for arbitrator challenges, and the guidelines on the interpretation of the threshold aim to reduce the incidence of bias. However, the grounds for arbitrators' disqualification inevitably contain loopholes. Not only is it grammatically impossible to cover all incidences of dependence or bias, ${ }^{1099}$ but excessively far-reaching grounds for arbitrators' disqualification would also undermine the parties' right to co-determine the decision-makers in ICSID arbitration proceedings, and would open the door to dilatory challenges and guerilla tactics. ${ }^{1100}$ Thus, it is impossible to entirely avoid the participation of a dependent or biased arbitrator on a tribunal.

As a consequence, it is necessary to deal with such residual pre-conceptions and biases in other ways than through disqualification. This book argues that the opposing positions of the party-appointed arbitrators can not only be neutralized, but can actually enrich the decision-making on the tribunal, and lead to a better thought-out and reasoned award, ${ }^{1101}$ as long as they are effectively

\footnotetext{
1099 See also Ball, supra note 45, at 324.

1100 Markert, supra note 21, at 241; LutTre LL, supra note 31, at 245; Park, Arbitration's Discontents, supra note 24, at 6o9; Park, Arbitrator Integrity, supra note 808, at 634 .

1101 See also Rogers, EтнICs, supra note 98, ๆ $8.60-8.61$ ("By systemically but constructively second-guessing the majority, and expressly challenging it when appropriate, partyappointed arbitrators can improve the process, within tribunal deliberations, in the process of drafting the award and by, in some cases, actually writing a dissent.... Under this view, party-appointed arbitrators are not a necessary evil that must be tolerated to make parties feel comfortable or because there are no viable alternatives. They are, instead, an important structural feature of international arbitral tribunals.").
} 
incorporated into the deliberations process. How such an involvement of all views can be achieved, and how the excessive control of a potentially predisposed party-appointed arbitrator over the proceedings can be avoided, is an important question.

One possible answer is the strengthening of the chairperson's influence, by ensuring that she or he has the highest possible degree of experience, authority and neutrality. By ensuring that the chairperson is experienced and skilled at managing arbitral proceedings and deliberations on the tribunal, that he or she has authority over the party-appointed arbitrators, and that he or she is neutral, any excessive influence of one of the party-appointed arbitrators could be avoided, and the incorporation of the positions of both party-appointed arbitrators into the deliberations ensured. ${ }^{1102}$ Tribunal chairs should therefore be appointed from an exhaustive roster, compiled of the most experienced arbitrators who have a track-record of neutrality - i.e. who have received roughly the same number of appointments from claimants and respondents, respectively - and authority (hereinafter the Panel of Chairmen).

Already today, the experience and authority of the most frequently appointed chairpersons is beyond doubt. The top fifty chairpersons in investor-State dispute settlement proceedings - all of whom have been appointed as chairpersons in at least four investor-State arbitrations - are either very experienced investment arbitrators or otherwise highly regarded international lawyers. ${ }^{1103}$

1102 See also Kapeliuk, Collegial Games, supra note 33, at 293 (stressing the importance of "an arbitrator's persistence and the effectiveness of his ability to communicate and convince the other arbitrators."); Sergio Puig, Social Capital and the Limits of Network Analysis, EJIL: Talk! Blog of the European Journal of International Law (Sept. 29, 2014), http:// www.ejiltalk.org/response-to-comments-on-social-capital-in-the-arbitration-market/ (highlighting the importance of the deliberative process and the diversity of views for a fair process and outcome). The need for a strong chairperson is further illustrated by the recent independence and impartiality fiasco in the PCA proceeding between Slovenia and Croatia (see supra Chapter 3, Part 4.3). The tapped phone conversations between Mr. Sekolec and Ms. Drenik suggest that the chairman had effectively excluded the partyappointed arbitrators from a part of the deliberations, in order not to compromise the unbiased outcome of the proceeding. Mr. Sekolec nevertheless intended to "work on Simma," the chairman in the proceeding (Ross, Tapped Conversations, supra note 915).

1103 See List of Presiding Arbitrators, unctad Investment Policy Hub, Investment Dispute Settlement Navigator, http://investmentpolicyhub.unctad.org/ISDS/ FilterByArbitrators (chairpersons appear in order of the number of their appointments in the drop-down entitled "President"). The number of party-appointments received by the top fifty chairpersons (see id., search "Appointed by claimant" and "Appointed by / Designated to Respondent" for respective arbitrator names) shows that only fourteen of them have arbitrated less than three investor-State disputes (i.e. "publicly known 
Many of them, however, have acted as party-appointed arbitrators in the past, and have as such predominantly been appointed by one side - whether by investors ${ }^{1104}$ or by States. ${ }^{1105}$ Even though such appointment patterns may be objectively justifiable, and need not be an indication of bias, they are likely to raise doubts regarding the neutrality of these chairpersons in the eyes of a reasonable third person. By only including arbitrators who do not raise such doubts, who exhibit a balanced appointment pattern when appointed by the disputing parties, and who therefore appear particularly neutral, on the Panel of Chairmen, the parties' confidence in the neutrality of the dispute settlement system could be strengthened.

IIA-based international investor-State arbitration proceedings," as defined by UNCTAD, see id., "About" tab) as party-appointed arbitrators. All of these fourteen arbitrators are otherwise highly experienced commercial arbitrators, or have gained meaningful dispute settlement expertise by virtue of their service on the Iran-us Claims Tribunal, on national Supreme Courts or international courts. Yet others have served in important functions with the World Bank or are scholars specialized in investment dispute settlement.

1104 See id. (search "Appointed by claimant" and "Appointed by / Designated to Respondent" for respective arbitrator names). Professor Kaufmann-Kohler, for example, who served as a chair in thirty proceeding registered in the database, was appointed by claimants in fourteen instances, but only twice by respondents. Mr. Fortier chaired twenty-one tribunals, and received twenty-two appointments by claimants, but only one by a respondent. Professor Orrego Vicuña was appointed by claimants in twenty-five cases, compared to three appointments by respondents. He served as the chairman in seventeen proceedings. Mr. Hanotiau served as the chairman in eleven cases, as the claimant-appointed arbitrator in fourteen investor-State arbitration proceedings, and was appointed by respondents in three instances. Mr. Lalonde and Mr. David A.R. Williams both chaired eight tribunals, and have predominantly been appointed by claimants when acting as party-appointed arbirators: Mr. Lalonde received nineteen appointments from claimants and four by respondents, while Mr. Williams was appointed by claimants in thirteen cases, but never by a respondent. Finally, Gary Born and Charles N. Brower both chaired one investor-State arbitration tribunal each, and have never been appointed by respondents, but served as claimant-appointed arbitrators in fourteen and thirty-nine instances, respectively.

1105 See id. (search "Appointed by claimant" and "Appointed by / Designated to Respondent" for respective arbitrator names). For example, Mr. Oreamuno Blanco chaired eleven investor-State arbitration tribunals, and served as the respondent-appointed arbitrator in fifteen cases. He has never been appointed by a claimant. Professor Dupuy was the chairman in seven instances, and was appointed by respondents in fourteen investor-State disputes. He was only appointed by the claimant in one case. Professor Stern chaired four tribunals and was appointed by respondents in seventy-four disputes, but never served as the claimant-appointed arbitrator. Mr. von Wobeser served as the chairman in four investor-State arbitrations, as the respondent-appointed arbitrator in twelve cases, and as the claimant-appointed arbitrator in one instance. 
A useful resource for the compilation of the Panel of Chairmen would be the network analysis conducted by Puig, ${ }^{1106}$ which could help to identify potential candidates who have frequently served as chairmen in the past, who have not predominantly been appointed by a particular category of parties (investors or States), and who are widely respected in the investment arbitration community.

The Panel of Chairmen should be compiled by a committee established within the ICSID Administrative Council (hereinafter referred to as the Appointment and Confirmation Committee), ${ }^{1107}$ which would ensure that the above-mentioned criteria are met. By delegating the choice of candidates for the panel to such a committee, instead of letting the Contracting States choose their nominees, politically motivated wrangling and ensuing delays in the selection process could be avoided.

Potential concerns about the transparency and legitimacy of such a nomination process ${ }^{1108}$ would be mitigated by the fact that the Appointment and Confirmation Committee would only choose the candidates for inclusion on the Panel of Chairmen. Meanwhile, the choice of the chairperson among these candidates, in a specific arbitration proceeding, would remain the prerogative of the parties, their counsel or the co-arbitrators. Thus, the parties would retain the control over the appointments which they value so highly.

The workload of the Appointment and Confirmation Committee would be manageable, since it would not be required to make appointments in specific disputes. Furthermore, the risk of political appointments would be reduced to one of three arbitrators, and largely eliminated if the requirements for nomination to the Panel of Chairmen were spelled out explicitly. Even if the Panel of Chairmen were very small and repeat appointments would therefore be common, an increased risk of conflicts of interest seems unlikely, because the chairpersons would be jointly appointed by both parties. Chairpersons are therefore never incentivized to please only one of the disputing parties, but rely on both parties' perception of their neutrality and fairness.

\subsection{Institutional Confirmation of Party-appointed Arbitrators}

The confidence of parties in the ICSID system can be impaired by the sheer number of challenges alone, irrespective of their merits. The most frequent

1106 Puig, Social Capital, supra note 36.

$1107 \mathrm{See}$, in the context of a proposed revision of the appointment method for ad hoc Committees, Collins, supra note 966 , at 340.

1108 Susan D. Franck \& Leah D. Harhay, Bridging the Divide Between Theory and Practice - An Introduction by the Conference Co-Chairs, 6 World ARb. \& Mediation Rev. 561 (2012). 
explanation given by scholars for their engagement with the question of independence and impartiality bears testament to this: Neither specific deficiencies of the challenge threshold or its application, nor a finding of an acute lack of independence and impartiality have led a multitude of scholars to deal with this issue. Instead, it is the increase in the number of arbitrator challenges in the past years, which has predominantly aroused their interest. ${ }^{1109}$ Against this background, a reduction in the overall number of challenges, and the avoidance of particularly problematic conflict situations from the outset would significantly improve the system's perceived legitimacy. Both goals could be achieved by requiring an institutional confirmation of the arbitrators nominated by the parties, similarly to the system under the ICC Arbitration Rules. ${ }^{1110}$

The requirement of a confirmation of party-nominated arbitrators by the Appointment and Confirmation Committee ${ }^{1111}$ would allow for compulsory disqualification grounds (see below, Chapter 5, Part 2.1) to be examined prior to the commencement of the proceeding. By performing routine checks for the most serious grounds for disqualification, particularly striking conflicts of interest could be avoided from the outset, without the drawback of a procedural delay ${ }^{1112}$ which a challenge would entail. Furthermore, the overall number of challenges would be reduced. ${ }^{1113}$ As a consequence, the parties' confidence in the arbitral tribunal, and in the dispute settlement system as a whole, would be improved. ${ }^{1114}$

The Appointment and Confirmation Committee should not only investigate whether imperative disqualification grounds exist, but should also examine the merits of parties' objections against arbitrators. In order to avoid subsequent procedural delays to the largest extent possible, party objections regarding all circumstances which are known at this early stage of the arbitration, and which could raise justifiable doubts as to the arbitrators' independence and impartiality, should be heard. Most objections against arbitrators could thus be dealt with prior to the commencement of the arbitral proceeding. This anticipated verification of arbitrators' independence and impartiality would

1109 Fry and Stampalija, supra note 31, at 190; Reinisch and Knahr, supra note 24, at 103-104; Levine, supra note 45 , at 2.

1110 ICC Arbitration Rules art. 13.

1111 See Collins, supra note 966, at 340 (suggesting the establishment of such a committee in the context of a proposed revision of the appointment method for ad hoc Committees).

1112 See DAELE, supra note 51, ๆ 6-079 (explaining that a procedural delay might result, inter alia, from the replacement arbitrator's need to study the file, and a possible repetition of certain procedural steps, such as the hearings on the merits).

1113 Schwartz And Derains, supra note 87, at 136.

1114 Whitesell, supra note 719, at 13 (in the context of arbitral tribunals under the ICc Arbitration Rules). 
signal to parties, counsel and arbitrators - but also to the wider public - that unbiased decision-making is an issue which is taken seriously in the ICSID system. Only potential conflicts of interest which are not yet known, or which arise in the course of the proceeding, would not be covered by the institutional confirmation requirement. By examining a majority of potential grounds for dependence or bias prior to the commencement of the proceeding, dilatory challenges could be reduced to some extent.

Objections raised by the parties at this stage of the proceedings should not be communicated to the arbitrators. ${ }^{1115}$ Although this would prevent arbitrators from providing potentially helpful information on the relevant circumstances, 1116 it would also avoid the discomfort and embarrassment of a challenge, ${ }^{1117}$ and prevent any grudge or bias of the arbitrator toward the objecting party. Concerns about the relevant arbitrator's partiality would not be reinforced as a consequence of the challenge.

Overall, the number of challenges could significantly be reduced if compulsory disqualification grounds and parties' allegations of bias were examined before the commencement of the proceeding. By not disclosing the parties' objections to the relevant arbitrator, the aggravation of the perception of bias could be avoided. This suggestion would retain the parties' control over the appointment of the decision-makers, but limit it procedurally, and ensure the pre-eminence of independence and impartiality, by requiring the institution's confirmation of the candidates.

By involving a permanent institution such as the above-suggested Appointment and Confirmation Committee, information about the arbitrators' previous appointments and challenges could be centralized and made fruitful for

1115 In the context of arbitrator challenges after the commencement of the proceeding, ICSID Arbitration Rule 9, para. 3 offers the arbitrator an opportunity to provide explanations. In practice, however, many arbitrators merely reaffirm their ability to decide the matter independently and impartially, without furnishing explanations. See Kinnear and Nitschke, supra note 13 , at 47 .

1116 See, in the context of the AaA Rules, Rogers, Ethics, supra note 98, ๆ 2.65 n.113; GARY B. Born, International Commercial Arbitration 1965 (2014). Since the situation is to be assessed from the perspective of a reasonable third person, the arbitrator's insider view and explanations are beyond the scope of enquiry, and her or his input is negligible.

1117 DAELE, supra note 51, $95^{-110}$ ("the challenged arbitrator will sit in judgment over the challenging party who had the audacity to attack his/her integrity."); Rogers, ETHICs, supra note 98, ๆ 2.65 ("For arbitrators, being challenged is generally an uncomfortable process. Their conduct is being questioned in front of their colleagues. The prospect of professional embarrassment can be quite real, even for the most esteemed and established arbitrators."). 
the confirmation process. Thus, the success of objections or challenges would not be as dependent on arbitrators' (possibly incomplete) disclosures. At least problematic repeat appointments, role switching und issue conflicts could be taken into account ex officio. For the sake of predictability, it would even be conceivable that such a committee would give arbitrators an advance warning in confirmation decisions, for example in the case of repeat appointments, by clarifying that the appointment at issue is the last acceptable appointment by a certain party or counsel, within a set time-frame.

\subsection{Institutional Jurisdiction for Arbitrator Challenges}

Finally, the competence to decide arbitrator challenges should be left to the Appointment and Confirmation Committee, instead of the unchallenged co-arbitrators.

The decision of arbitrator challenges by the unchallenged arbitrators is a unique feature of the ICSID system, which has frequently been criticized: It is generally assumed that the members of the close-knit community of investment arbitrators are sympathetic towards each other, and that they might have a tendency to protect each other against challenges. ${ }^{1118}$ Some scholars even raise concerns about cronyism. ${ }^{1119}$ Since most challenges are directed against party-appointed arbitrators, at least one of the decision-makers in such challenge proceedings (the chairperson) usually owes their position to the challenged arbitrator. Accordingly, the unchallenged arbitrators do not appear as free in their decision-making as would be desirable. At least subconsciously, they might be guided by sympathies and allegiances, and by the distant thought that they might one day find themselves in the same situation, and depend on their co-arbitrators' loyalty and trust.

Aside from potential sympathies for the challenged arbitrator, the coarbitrators' evaluation of a challenge after the commencement of the proceeding risks to either be influenced by their preliminary views on the merits of the case (and hence their sympathies for one or another party), or even worse, to affect their view on the substance of the proceeding. The merits of a challenge and the merits of a party's claim for damages, however, are entirely unrelated, and should not impact each other.

1118 Markert, supra note 21, at 248-250 (including further references); Fry and Stampalija, supra note 31, at 257-258; Tupman, supra note 43, at 32; Reinisch and Knahr, supra note 24, at 123; Rubins and Lauterburg, supra note 32, at 163; Nadakavukaren Schefer, supra note 82 , at 233 .

1119 Giorgetti, Challenges, supra note 32, at 316-317; Rubins and Lauterburg, supra note 32, at 163 . 
Another factor which may influence the co-arbitrators' decisions on arbitrator challenges is their embedding in the arbitration community. They might effectively be so used to certain customs, that they are unable to examine a disqualification proposal from the perspective of an (uninvolved) reasonable third person. ${ }^{1120}$ They are more likely to find certain connections between arbitrators and other participants in the proceeding to be ubiquitous, and inherent in the system, and to dismiss doubts about an arbitrator's independence or impartiality on this basis.

Decisions on arbitrator challenges should therefore be delegated to distinct decision-makers. The transfer of the decision-making authority to an institutional body would also improve the consistency of future challenge decisions, and allow for a thorough consideration of the challenging party's claims. ${ }^{1121}$ The certainty that challenges are "comprehensively investigated and subject to rigorous legal scrutiny"1122 would ensure the parties' acceptance of unfavorable decisions, and strengthen the system's perceived legitimacy. Last but not least, assigning the same institution with the confirmation of arbitrators and with deciding arbitrator challenges would make sense from the perspective of procedural economy, specialization, and in order to allow for a centralization of the pertinent information. ${ }^{1123}$

\section{Guidance on the Interpretation of a Justifiable Doubts Threshold}

As stated above, the concept of justifiable doubts is inherently malleable. ${ }^{1124}$ As useful as this is for the adaptability of the threshold to various dispute resolution mechanisms, it is also potentially harmful for the effectiveness of the

1120 See also Kee, supra note 22, at 195 .

1121 See, in the context of the Iran-Us Claims Tribunal, Caplan, supra note 271, at 120-121 ("The written decisions of the Appointing Authority with respect to challenges of arbitrators, on the whole, have reflected the careful analysis of an eminent legal mind. The long tenures of the Appointing Authority ... have fostered the development of a rich and largely consistent jurisprudence."). The Appointing Authority of the Iran-us Claims Tribunal conducted interviews with the challenging party and the challenged arbitrator, since documentary evidence was often considered insufficient - a course of action which would be equally advisable in ICSID arbitration.

1122 Caplan, supra note 271, at 121.

1123 See Id. at 120 in the context of the Iran-Us Claims Tribunal ("These conditions have also assisted in the development of an effective and efficient practice of investigation and evidence gathering in the context of resolving challenges.").

1124 Supra Chapter 4, Part 3.2, p. 209. 
parties' right to an independent and impartial decision-maker. The qualitative standard ${ }^{1125}$ provides little guidance for appointments, challenges and recusals, and leaves tremendous discretion to those dealing with disqualification requests. ${ }^{1126}$ In light of the limited precedential value which arbitrators accord to past challenge decisions, the vagueness of the threshold can lead to inconsistencies in decisions on arbitrator challenges. A consistent application of the threshold in disqualification decisions, however, is pivotal for improving the perception of arbitrators' independence and impartiality, and for enhancing the legitimacy of ICSID arbitration. The only way to achieve such consistency is by putting the justifiable doubts threshold into more concrete terms - in the words of Rogers: into quantitative standards. ${ }^{1127}$

The IBA Guidelines already contain quantitative standards of arbitrator independence and impartiality. They are however of limited usefulness in the investment arbitration context. In most situations, the outcome of a challenge is inconclusive - either because the specific circumstances are not provided for in the Application Lists, or because they are merely listed in the Orange List (which refers back to the general justifiable doubts threshold, instead of conclusively settling the question of disqualification). Furthermore, the valuations implied in the Application Lists reflect that the IвA Guidelines were drawn up mainly with commercial arbitration in mind. As highlighted by the unchallenged arbitrators in Highbury, a stricter approach is warranted in investment arbitration, because of the public interests which are frequently affected. ${ }^{1128}$

In order to clarify the permissibility of frequently arising potential conflict situations, application lists similar to those of the IBA Guidelines should be drawn up specifically for ICSID arbitration. Such a course of action would be in line with the frequent criticism of the IBA Guidelines' one-size-fits-all approach, ${ }^{1129}$ and would present a unique opportunity to transcend the minimum agreement that the IBA Guidelines represent. ${ }^{1130}$ It would further allow

1125 Rogers, Ethics, supra note 98, ๆ 6.69.

1126 Trakman, supra note 819, at 127 ("[T]his is an age old debate that offers no new insights except to observe that the reasonable person is amorphous, not a fixed and constant being."); Rogers, Еthics, supra note 98, ๆ 2.67 .

1127 Rogers, Ethics, supra note 98, \ 6.73 .

1128 Highbury, ๆ $84-85$.

1129 Mouawad, supra note 252, at 1 and 11; Rog ERs, ETHICS, supra note 98, ๆ 6.80; Rubins and Lauterburg, supra note 32, at 164 ("[T] he IвA Guidelines may in certain respects be inherently ill-suited to the investment arbiration context."); Bernasconi-Osterwalder, Johnson, and Marshall, supra note 32 , at 31 .

1130 Horvath and Berzero, supra note 37, at 18; Trakman, supra note 819, at 126; Ball, supra note 45 , at 325 . The IBA Guidelines are a "lowest common denominator" in several ways. 
for an open and transparent discussion of the practical implications of the categorization, and reduce the uncertainty that arbitrators, parties and those who have to decide challenges otherwise face.

A first proposal for such ICSID-specific conflict of interest guidelines will be made hereinafter, with the intention of inspiring a further discussion of the issue. It is informed by past disqualification decisions in the ICsID system as well as in the other dispute resolution systems examined in Chapter 3.

\subsection{Compulsory Grounds for Disqualification}

Certain situations raise such grave doubts about an arbitrator's independence and impartiality that he or she should not accept the appointment, or should recuse him- or herself. Besides the possibility of challenging an arbitrator based on such circumstances, the existence of such constellations should be examined prior to the commencement of the proceeding, in a confirmation proceeding before the above-mentioned Appointment and Confirmation Committee. ${ }^{1131}$ If a compulsory disqualification ground exists, and the arbitrator refuses to step down voluntarily, he or she should not be confirmed, and the relevant appointing party should be given another opportunity to appoint an appropriate, independent and impartial arbitrator.

By performing such routine checks for the most serious grounds for disqualification, certain particularly striking conflicts of interest could be avoided from the outset, without the drawback of a procedural delay which a challenge would entail. A clear list of compulsory disqualification grounds and their effective enforcement in confirmation and disqualification procedures would signal to parties, counsel and arbitrators - but also to the wider public - that unbiased decision-making is an issue which is taken seriously in the ICSID system, so much that its core content is not subject to the parties' timely complaint. Such an approach would enhance the general perception of the ICSID system's legitimacy, and of its decision-makers' integrity.

The imperative disqualification grounds should be enumerated in an exhaustive list which is formally similar to the IвA Guidelines' Red Lists. ${ }^{1132}$ In investment arbitration, however, all situations included on a red list should

They are the minimum protection on which an international community of commercial, financial and investment arbitrators was able to agree. Accordingly, they have often been criticized for lacking the potential to answer the most pressing questions. See, e.g., Levine, supra note 45 , at 62 .

1131 Similarly to the system under ICC Arbitration Rules art. 13, see supra Chapter 3, Part 2.4; BÜHLER AND WEBSTER, supra note 720, ๆף 11-31 (1st ed. 2005).

1132 Wouters and Hachez, supra note 19, at 636. 
lead to the arbitrator's disqualification, without the possibility of a waiver. The frequent involvement of public interests requires situations which are of such gravity as to be on a red list to be imperative grounds for the arbitrator's removal, and not subject to party autonomy.

Because of the far-reaching consequences of including a constellation on this list, it is important that the list be narrowly construed. The grounds for disqualification should first of all be informed by the ICSID disqualification decisions which have been upheld in application of the justifiable doubts standard. These decisions should represent a baseline for situations which imperatively require an arbitrator's disqualification (similarly to the IBA Guidelines' Red Lists).

The list should further be expanded with situations which have consistently led to disqualifications in the other examined dispute resolution mechanisms. Where a consensus requiring the arbitrator's disqualification in certain conflict categories spans most comparable dispute settlement mechanisms, ${ }^{1133}$ such situations should imperatively lead to an arbitrator's disqualification in the ICSID system, too. As explained, investment arbitration rules should be stricter than international commercial arbitration with regard to disqualification grounds, if anything, and not more lenient.

Accordingly, attorney-client relationships between an arbitrator or the arbitrator's law firm ${ }^{1134}$ and a party should be considered incompatible with the arbitrator's appointment, irrespective of the subject-matter of the attorney-client relationship. For the same reasons, all circumstances on the NonWaivable and Waivable Red Lists of the Іва Guidelines should be included on the list of compulsory disqualification grounds.

Certain constellations which are specific to investment arbitration should be dealt with more strictly than they have been so far: They should invariably

1133 CARON AND CAPLAN, supra note 91, at 211-213 (explaining that there is large consensus in the international commercial arbitration community regarding the "circumstances thought to provide 'absolute' grounds for challenge," such as an arbitrator's direct financial and personal interest in the outcome of the proceeding and certain specified close ties between the arbitrator and a party.).

1134 Connections of the arbitrator's law firm should generally be imputed to the arbitrator. It is impossible to effectively police the separation of the law firm's and the arbitrator's interests (e.g. through Chinese Walls), and the risk of an indirect influence on the arbitrator's decision-making is therefore too serious to be ignored. The diffusion of international arbitration practice groups and revenue sharing practices in international law firms, together with the important governance function of arbitrators and the public interest nature of investment disputes warrants a strict approach. See Bernasconi-Osterwalder, Johnson, and Marshall, supra note 32, at 32; Mullerat овE, supra note 714, at 64 . 
lead to the arbitrator's non-confirmation or disqualification. One such situation is the repeat appointment of the arbitrator by the same party or a party and its affiliate (or a counsel or law firm) in proceedings concerning claims based on the same or highly similar factual circumstances and / or on the same or similar legal grounds. Irrespective of whether the appointments in question were parallel or subsequent, the arbitrator is asked to deal with the same or highly similar issues, in the expectation that she or he would ensure coherent outcomes in favor of the appointing party in both proceedings. It is realistic to assume that the appointing party values the arbitrator's favorable influence on the tribunal's deliberations more highly than the coherence of the decisions. Thus, the parallel or subsequent appointments of the same person are indicative of the appointing party's trust towards the arbitrator and its confidence that he or she will reach a beneficial result. To a reasonable third person, the appointments create the appearance that either the arbitrator feels allegiance to the appointing party, or that his or her opinion is set in stone from the outset, so that the appointing party can rely on achieving its desired outcome. In both situations, the arbitrator would lack the requisite independence or impartiality.

The described doubts regarding the arbitrator's objective and rational decision-making are not attenuated if only the facts or only the legal questions of the cases overlap. Past ICSID challenge decisions have required an overlap of all elements: the appointing party, the legal questions and the factual circumstances. ${ }^{1135}$ The threat to the arbitrator's unprejudiced decision-making, however, is just as pronounced if only some of these elements overlap, or if the factual or legal questions are only similar. In such situations, the danger of seeing a familiar pattern in a situation which is only similar to a previous case, and of missing important differentiating elements, might be even more serious.

Another situation that begs for a non-confirmation or disqualification is the appointment of an arbitrator who has co-authored a previous award which was either directed against one of the parties to the arbitration, or which concerned the same (narrow) subject-matter as the current proceeding, if the previous award was annulled (in both situations). Since the reasons for an annulment of an award are strict, and annulments are therefore rare, it is not unreasonable to assume that arbitrators who have participated in the making of an award are taken aback by its annulment. They may perceive the annulment of the award as a criticism of their work and be prejudiced towards the party which requested the annulment, or feel the urge to justify the considerations that led to the annulled award, by deciding similarly in a subsequent proceeding.

1135 See supra Chapter 2, Part 2.5. 
Such arbitrators might effectively appear to "[make] the case [their] own" - a mindset which is generally held to justify the decision-maker's disqualification. ${ }^{1136}$ It appears unlikely that an arbitrator would change his or her mind on a legal issue, as a consequence of an annulment - in particular in light of the lack of a system of binding precedent in arbitration - or that he or she would have a neutral attitude towards a party which has requested the annulment of the award co-authored by the arbitrator. The appointment of arbitrators with such a record is not a coincidence, but rather a calculated move by the appointing party, which seeks to ensure a particular outcome of the case. This expectation, together with the potential biases mentioned above, raises justifiable doubts about the arbitrator's ability to dispassionately analyze the case and to objectively and rationally apply the law to it. It is understandable that such a situation would impair the counterparty's confidence in the proceeding, and its ultimate acceptance of the award - in particular if the annulment of the previous award and the arbitrator's appointment are chronologically close together. Accordingly, such arbitrators should not be confirmed within a transitional period of three years after the annulment.

Furthermore, role switching between an arbitrator and a counsel in concurrent proceedings should imperatively lead to non-confirmation. As Fry and Stampalija highlight, the awareness that a counsel in the present proceeding will adjudicate a matter in which the arbitrator serves as a counsel might (subconsciously, at least) influence the arbitrator's decision, or appear to influence it. ${ }^{1137}$ In cases in which the outcome is not evident, at least, the arbitrator might be reluctant to decide against the party represented by a counsel who will later decide on a dispute argued by the arbitrator, in order not to diminish his or her chances in said proceeding. The risk which such constellations entail for the parties' confidence in the ICSID system is conveyed by the comparison of the arbitration community to a "mafia," based on such circumstances:

Now why is it a mafia? It's a mafia because people appoint one another. You always appoint your friends - people you know.

They nominate one another. And sometimes you're counsel and sometimes you're arbitrator. ${ }^{1138}$

Such constellations should be avoided. Instead of removing the arbitrator in the first proceeding, who might appear at risk of being biased, however, the

\footnotetext{
1136 Franck, Structure, supra note 41, at 251-252.

1137 Fry and Stampalija, supra note 31, at 251.

1138 DeZalay and Garth, supra note 1024, at 50.
} 
confirmation of the arbitrator in the second proceeding should be withheld. Thereby, a conflict of interest in the ongoing proceeding could be avoided, without any unnecessary delay, simply by requiring the appointment of another arbitrator in the second proceeding. For the avoidance of doubt, such serious consequences should only ensue if the two proceedings in which the role switching occurs overlap chronologically, so that the arbitrator in the first case could be aware of the counsel's function in the second proceeding, before the award is made.

Situations in which an arbitrator could prejudge a proceeding in which he serves as a counsel - i.e. a concurrent proceeding in which the same specific legal questions are outcome-determinative - must also be avoided. Accordingly, such arbitrators should be disqualified. ${ }^{1139}$

\subsection{Potential Grounds for Disqualification}

Circumstances which neither imperatively call for the arbitrator's removal, nor are exempt as grounds for disqualification, shall be examined in application of the justifiable doubts standard on a case-by-case basis. They should be enumerated illustratively on a list of potential grounds for disqualification, which should further be subdivided into two categories: situations which presumably raise justifiable doubts, unless the arbitrator can dispel them, and situations in which justifiable doubts are not presumed, but must be demonstrated by the challenging party. This subdivision - and the reversal of the burden of proof in the first subcategory - intends to reduce the unpredictability for all participants in the proceeding, and to signal which situations are considered to be particularly problematic.

Some uncertainty with regard to an arbitrator's qualification to serve in a specific dispute is however inevitable. The described situations are abstract simplifications of more complex real world constellations, which considerably vary on a very detailed level. Just like the IBA Guidelines, ICsID-specific guidelines cannot possibly provide for all contingencies, and must therefore remain flexible enough to allow for a case-by-case analysis. The uncertainty thereby created can however have advantages in practice, if all participants in the system seek to avoid such constellations, in order not to be vulnerable to the counterparty's challenges. The IBA Guidelines' provisions on repeat appointments, which are only on the Orange List, appear to have such a deterrent effect. ${ }^{1140}$

1139 DAELE, supra note 51, ๆ 7-003; Park, Arbitrator Integrity, supra note 808, at 648-649.

1140 See supra Chapter 3, Part 3.3. 
By construing this list of potential disqualification grounds narrowly, with a focus on problematic situations which frequently occur in practice, the predictability of challenge proceedings would be improved for parties, counsel and arbitrators: Reputational risks would be diminished for arbitrators, while parties and counsel could make their appointments prudently, so as not to expose themselves to strategic challenges by their counterparties.

The following situations should be included on the first list of potential grounds for disqualification, which entails a presumption of justifiable doubts:

Repeat appointments by the same party or counsel in three or more cases within three years should be presumed to raise justifiable doubts as to the arbitrator's independence and impartiality, irrespective of the arbitration rules which govern the relevant proceedings. ${ }^{1141}$ The same presumption should apply if the arbitrator is appointed in three or more cases against the same party within three years, if those appointments make up for a significant part of her or his overall appointments. The threshold suggested for those constellations is the same as that provided for in $\S$ 3.1.3 IBA Guidelines, with respect to repeat appointments by a party: three years. ${ }^{1142}$ By limiting the number of admissible repeat appointments, this suggestion takes into account that repeat appointments may raise justified concerns about arbitrators' dependence on their

1141 See also Sobota, supra note 27 , at 317 . As in most other systems, party and counsel appointments should be added up in challenges under the ICsID Convention and Arbitration Rules, for parties and their counsel act together from the perspective of the challenging party, and the disputing parties' choice of arbitrator is often significantly influenced by their counsel (see DAE LE, supra note 51, ๆ 6-191).

1142 From a practical perspective, it appears easier to implement a rule which many practitioners (who are active in different arbitration systems, see Horvath and Berzero, supra note 37, at 15) are already familiar with it. See, in this context, the statement of one of today's most influential arbitrators, and a Judge of the Iran-Us Claims Tribunal, Charles N. Brower: "I do not accept appointments ... by the same party or on the recommendation of the same counsel within the preceding three years. In fact, this situation is easy to avoid, unlike some of the other challenges that have been discussed, where the issues are more nuanced." (Brower, Melikian, and Daly, supra note 877, at

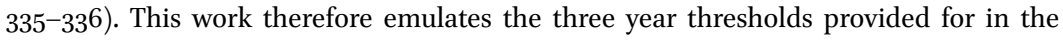
IBA Guidelines, despite noted criticism. See Trakman, supra note 812, at 135 ("[W]hy should it be three years and three appointments? Is there any magic in the number three?"). 
appointing party or counsel, ${ }^{1143}$ or arbitrators' bias. ${ }^{1144}$ The reversal of the burden of proof reflects the increased importance of independence and impartiality in the ICSID system, due to the public interests involved in the proceedings. ${ }^{1145}$ The proposal does not, however, draw an arbitrary line beyond which arbitrators cannot serve. Arbitrators who surpass the stipulated thresholds may still serve, if they can dispel any justifiable doubts about their independence and impartiality, and thereby remove the presumption of bias. Thus, the parties' autonomy to appoint suitable and qualified arbitrators is not unnecessarily or disproportionately constrained.

This proposition equates party-appointments and appointments by counsel in terms of the limits on repeat appointments, based on the belief that there is no objective reason to apply a higher threshold to appointments by counsel than to party-appointments, as is done in the IвA Guidelines. ${ }^{1146}$ Arbitrators are most often appointed by counsel, and not by the parties themselves. Accordingly, their incentive to please a particular law firm is at least as high as the temptation to favor "their" party. Justifications of a higher threshold for repeat appointments by counsel appear to be based on the view that contacts between an arbitrator and a counsel are inevitable. ${ }^{147}$ Mere contacts or prior acquaintances, however, are not the same as prior appointments. Thus, there is no justification for a disparate treatment of repeat appointments by parties or by counsel. By imposing the same limits on parties and counsel, this suggestion would noticeably disentangle long-term co-operations between law firms and arbitrators which reinforce the perception of the arbitrator as an extension of counsel, and would rebut accusations that the investment arbitration community is a mafia.

Another innovation of this proposal is to limit repeat appointments against a party, subject to the same thresholds, and if they make up for a significant part of the arbitrator's overall appointments. There is no point of reference on how to handle such appointments in any of the examined dispute resolution

1143 DAELE, supra note 51, If 6-157; Slaoui, supra note 85, at 103; Shany, supra note 106, at 485 n.64; Smit, Pernicious Institution, supra note 940.

1144 Sobota, supra note 27, at 295. See also the arguments of the investors in Tidewater and Universal Compression.

1145 See Highbury, ๆ $84-85$ (holding that the thresholds stipulated in the IBA Guidelines should be stricter in the ICSID system, because of the public interest involved in investment arbitration); DAELE, supra note $5^{1}$, 9 5-107.

1146 IвA Guidelines, Application Lists, $\S 3.1 .3$ (setting the threshold at three appointments within three years for appointments by a party) and $\S 3.3 .8$ (setting the threshold for appointments by counsel at four appointments within three years).

1147 See Sobota, supra note 27, at 298; Markert, supra note 21, at 255. 
systems or in the IBA Guidelines, because the problem is specific to investment arbitration. Repeat appointments against a party are systemically less likely to occur in commercial arbitration (and hence in proceedings governed by the ІвА Guidelines), because private respondents are just as numerous as claimants. In ICSID arbitration, however, the pool of respondents is limited. ${ }^{1148}$ Accordingly, appointments by different claimants in proceedings against the same State are possible, and have become a reality in proceedings against States which are frequently sued in the ICSID system. For example, Professor Francisco Orrega Vicuña has served in at least five proceedings against Argentina, ${ }^{1149}$ and was challenged on this basis. In such constellations, similar legal questions and factual circumstances are often at stake. Even when the cases are dissimilar, however, an appearance of bias can arise. Repeat appointments against a State are often based on prior statements of the arbitrator or on the outcome of previous proceedings, and premised on the expectation that the arbitrator will take a position which is favorable for the investor. The arbitrator has an incentive to comply with this expectation, in order to be reappointed in future disputes against the same State. If his or her views on legal or political issues relevant in the proceeding are aligned with the investor's interest to begin with, the prospect of being appointed in the future acts as a disincentive to critically and rationally reconsider the issues at stake. In principle, repeat appointments against a State should therefore generally be scrutinized just as critically as any other kind of repeat appointment. However, in order to take account of the limited pool of potential respondents and the resulting possibility of coincidental repeat appointments against a State, this proposal imposes an additional requirement on challenges based on such circumstances: namely, that they make up for a significant part of the arbitrator's overall appointments. In such constellations, the arbitrator would appear to be particularly likely to ensure future appointments by supporting his or her appointing party's position on the tribunal.

In all three repeat appointment constellations covered by this proposition repeat appointments by a party, by a counsel, or against a party - no overlap of the law and facts should be required. Such an overlap certainly intensifies existing doubts about the arbitrator's impartiality, it is however not necessary

1148 The pool of respondents is formally limited to the ICsID Contracting States. Even considering the possibility of proceedings under the Additional Facility Rules, the pool of potential respondents is not nearly as virtually unlimited as in commercial arbitration.

1149 Repsol, Sempra, cMs, Enron and Camuzzi International S.A. v. Argentine Republic (I), ICSID Case No. ARB/03/2. 
for the appearance of dependence or bias to arise. Furthermore, repeat appointments in cases concerning the same or highly similar factual circumstances and / or the same or highly similar legal questions are covered by $\S 3.1$ of the proposed list of compulsory disqualification grounds.

If the arbitrator has publicly expressed his or her view on questions which are relevant in the current dispute (by means other than academic publications), without however referring to the specific proceeding, this may also raise justifiable doubts as to his or her independence or impartiality. Unless the arbitrator can rebut the appearance of prejudgment created by such statements, he or she should be disqualified.

Justifiable doubts as to the requisite independence and impartiality should also be presumed if the arbitrator and one of the counsel in the proceeding have acted as co-counsel in more than three proceedings within three years. Setting the threshold at three proceedings within three years still allows for substantial collaboration among arbitration professionals, but limits such activity in conformity with the above rules on repeat appointments, for the same reasons.

B

Burden of Proof on the Challenging Party

The following situations should be included on the second list of potential grounds for disqualification, which does not entail a presumption of justifiable doubts, but requires their demonstration by the challenging party:

If an arbitrator has previously served as a counsel in a dispute, and one of the arbitrators in said proceeding now acts as a counsel to one of the parties, justifiable doubts regarding the arbitrator's independence and impartiality may arise if the proceedings are chronologically close together. While such constellations are less problematic than role switching in concurrent proceedings, they may still raise doubts about the arbitrator's ability to decide the case in an objective and rational manner. Whether the tribunal in the first proceeding (including the arbitrator who now represents one of the parties) decided in favor or against the arbitrator's client in that case, its decision might subconsciously influence the arbitrator's decision in the following proceeding. Doubts about the arbitrator's dispassionate and rational decision-making might be particularly strong if the proceedings are chronologically close, and the memory of the decision in the first case is still fresh. Accordingly, the time frame of three years, which is applied in the context of many other potential conflict situations in this proposal, as well as in the IBA Guidelines, should apply to this situation, as well.

If the arbitrator has previously adjudicated a dispute in which the same legal questions were relevant, and issued a dissenting or concurring opinion 
on a point of law which is determinative in the current proceeding, this may raise justifiable doubts as to his or her independence or impartiality. Other scholars request that such arbitrators should resign or be disqualified. ${ }^{1150}$ Such a strict approach would however discourage arbitrators from authoring dissenting or concurring opinions, and disregards the unique importance of dissenting opinions for the deliberative process on the tribunal, ${ }^{1151}$ and for the development of the law. ${ }^{1152}$ Thus, this proposal favors the determination of the arbitrator's independence and impartiality on a case-by-case basis, instead.

Academic publications may give rise to justifiable doubts as to the arbitrator's independence or impartiality, if they do not only concern general issues, but very specific legal questions which are decisive in the dispute at hand. Because such publications are important for the diffusion of knowledge and for the development of the law, ${ }^{1153}$ they should not be dissuaded by generally presuming that their author is biased. However, if the appearance of prejudgment exceeds the extent of preconceptions with which any arbitrator would

$115^{0}$ Mouawad, supra note 252, at 13.

1151 Peter Rees QC \& Patrick Rohn, Dissenting Opinions : Can they Fulfil a Beneficial Role?, 25 ARb. INT'L. 329, 330 (2009) (arguing persuasively that dissents can ease the deliberative process by "operat[ing] as a valve that reduces the pressure in an arbitration where, even after drawn-out deliberations, the arbitrators are not able to reconcile their views."); Kapeliuk, Collegial Games, supra note 33, at 297; Hans Smit, Dissenting Opinions in Arbitration, 15 ICC INT'L. Court Arb. Bulletin 37, 41 (2004) (explaining that "the prospect of a dissenting opinion may stimulate the deliberative process by encouraging dialogue between the disagreeing arbitrators.").

1152 See Rogers, Politics, supra note 17, at 242 et seqq.; Brower and Rosenberg, supra note 122, at 34 (pointing out that a dissent "offers a unique tool to produce a better arbitral award, given that [it] is likely to stress the weaknesses in the plurality's decision and force the plurality to address them in the factual and legal analyses in its decision." (internal quotations omitted)). Contra van den Berg, Dissenting Opinions, supra note 34, at 831 (arguing that "dissenting opinions ... barely serve a legitimate purpose in a system with unilateral appointments," and that investment arbitration would be "more credible if party-appointed arbitrators observe the principle nemine dissentiente," unless the majority opinion seriously violates due process or "the arbitrator has been threatened with physical danger absent a dissent."); Albert Jan van den Berg, Charles Brower's problem with 100 per cent - dissenting opinions by party-appointed arbitrators in investment arbitration, 31 Arb. InT'L. 381 (2015).

1153 DAELE, supra note 51, ๆ 7-190 ("The development of arbitration as a separate area of law and a mature dispute resolution mechanism partly depends on the scholarly attention paid to this system and to the quality of the scholarly writing."). 
approach a case, ${ }^{1154}$ and justifiable doubts as to the arbitrator's impartiality arise, the arbitrator should be disqualified. ${ }^{1155}$

Justifiable doubts may also arise if the arbitrator and one of the counsel in the proceeding have co-authored academic publications in the past three years. Again, because of the importance of academic publications, justifiable doubts as to the arbitrator's independence should not be presumed, or the coauthoring of such publications would be unnecessarily dissuaded. However, the intensive intellectual exchange which a co-authorship entails can raise doubts as to the arbitrator's ability to approach the arguments of such a counsel with the required distance and criticism. Accordingly, challenges based on such circumstances should be decided on a case-by-case basis, in application of the justifiable doubts standard.

If the arbitrator has regularly dealt with the same legal questions which are relevant in the current proceeding in his previous role as a public servant, his views may be excessively preconceived. If justifiable doubts as to his impartiality arise, for example because he or she has repeatedly dealt with the relevant legal question on numerous occasions, the arbitrator should be disqualified.

\subsection{No Grounds for Disqualification}

Situations which are consistently considered not to raise justifiable doubts as to an arbitrator's independence and impartiality in all examined dispute resolution mechanisms, and in which there is no reason for a different conclusion in investment arbitration, should be enumerated in a list of innocuous circumstances. One such constellation is the acquaintance of an arbitrator with a counsel, absent exceptionall156 circumstances. Another unproblematic

1154 Markert, supra note 21, at 263 ("[I]t would be unrealistic to expect that an arbitrator approaches a case without any kind of a preconception of the legal issues in dispute. This might be due to the arbitrator's legal education or due to the particular expertise for which the arbitrator was appointed in the case.").

1155 Natalia Giraldo-Carrillo, The "Repeat Arbitrators" Issue: A Subjective Concept, InT'L. L., Revista Colombiana de Derecho Internacional 75, 97-98 (2011).

1156 A close co-operation between the arbitrator's law firm and the law firm of counsel, in the form of shared office space and held joint seminars, for example, would qualify as such exceptional circumstances, which might raise justifiable doubts as to the arbitrator's independence and impartiality. The same applies to the repeated co-operation of an arbitrator and a counsel as co-counsel in proceedings (see infra Chapter 5 , Part 2.4 B., § 1.5). See also DAELE, supra note 51, ๆ 6-187 (additionally listing the following qualifying circumstances: The employment of a close relative of the arbitrator in the same law firm as a counsel, a close friendship between an arbitrator and a counsel, the prior co-operation of 
situation is the arbitrator's provision of a legal opinion on an issue which also arises in the arbitration, but without reference to the dispute, and in a very general manner. An arbitrator's remote contacts to another arbitrator or counsel, which merely consist in his or her membership in a professional association or the like, are also innocuous. Furthermore, certain constellations which are enumerated in the IвA Guidelines' Green List should also be included on the ICSID-specific list, as far they do not raise justifiable doubts as to the arbitrator's independence and impartiality.

\subsection{Proposal for ICsID-specific Guidelines on Conflict of Interest}

A Incompatibilities

An arbitrator should not accept his appointment, should recuse himself, or should not be confirmed in the following situations:

\section{Incompatible interests of the arbitrator}

1.1 The arbitrator has a significant direct or indirect financial or personal interest in one of the parties, or in the outcome of the case. ${ }^{1157}$

1.2 The arbitrator is a party in the proceeding, or a legal representative or employee of a party. ${ }^{1158}$

1.3 The arbitrator is a manager, director or member of the supervisory board, or has a controlling influence on one of the parties or an entity that has a direct economic interest in the award to be rendered in the arbitration. ${ }^{1159}$

1.4 The arbitrator holds shares, either directly or indirectly, in one of the parties, or an affiliate of one of the parties, this party or an affiliate being privately held. ${ }^{1160}$

1.5 The arbitrator is a manager, director or member of the supervisory board, or has a controlling influence in an affiliate of one of the parties, if the affiliate is directly involved in the matters in dispute in the arbitration. ${ }^{1161}$

1.6 The arbitrator is a lawyer in the same law firm as the counsel to one of the parties. ${ }^{1162}$

an arbitrator and a counsel as co-counsel, the previous employment of an arbitrator and a counsel in the same law firm, the arbitrator's and a counsel's membership in the same barristers chambers.).

1157 IBA Guidelines, Application Lists, § 1.3.

1158 IвA Guidelines, Application Lists, § 1.1.

1159 IBA Guidelines, Application Lists, $§ 1.2$.

1160 IBA Guidelines, Application Lists, $§$ 2.2.1.

1161 IBA Guidelines, Application Lists, § 2.3.4.

1162 IBA Guidelines, Application Lists, § 2.3.3. 
1.7 The arbitrator's law firm currently has a significant commercial relationship with one of the parties, or an affiliate of one of the parties. ${ }^{1163}$

1.8 The arbitrator has a close family relationship with one of the parties, or with a manager, director or member of the supervisory board, or any person having a controlling influence in one of the parties, or an affiliate of one of the parties, or with a counsel representing a party. ${ }^{1164}$

1.9 A close family member ${ }^{1165}$ of the arbitrator has a significant financial or personal interest in the outcome of the dispute, or in one of the parties, or an affiliate of one of the parties. ${ }^{1166}$

1.10 The arbitrator, or a close family member of the arbitrator, has a close relationship with a non-party who may be liable to recourse on the part of the unsuccessful party in the dispute. ${ }^{1167}$

\section{Incompatible legal services ${ }^{1168}$}

2.1 The arbitrator or the arbitrator's law firm regularly advise or represent a party or its affiliate. ${ }^{1169}$

2.2 The arbitrator or the arbitrator's law firm currently advise or represent the party. ${ }^{1170}$

1163 IBA Guidelines, Application Lists, § 2.3.6.

1164 IBA Guidelines, Application Lists, § 2.3.8.

1165 Throughout the Application Lists, the term "close family member" refers to a spouse, sibling, child, parent or life partner, in addition to any other family member with whom a close relationship exists. The same definition should apply in the ICSID context.

1166 IBA Guidelines, Application Lists, § 2.3.9.

1167 IBA Guidelines, Application Lists, § 2.2.3.

1168 Such services may be provided by the arbitrator or his law firm, to a party or its affiliate (encompassing all companies in a group of companies, including the parent company). The attorney-client relationship of a law firm which the arbitrator has only recently left should be considered under this category, and be treated the same if the modalities of the arbitrator's resignation from the law firm and his former position in the law firm reasonably create the impression that the arbitrator's continuing bond of loyalty towards the firm interferes with his dispassionate, objective and rational analysis of the case. In particular, if the arbitrator has been a partner within the firm, the firm's attorney-client relationships shall be imputed to the arbitrator during a phase-out period of three years (cf. IBA Guidelines, Application Lists, § 3.3.3).

1169 IBA Guidelines, Application Lists, $§ \S 1.4,2.3 .7$ and 3.2.3.

1170 IBA Guidelines, Application Lists, $\S \S 2.3 .1$ and 3.2.1 and Blue Bank, expanded based on the examined commercial arbitration case law, and to reflect the particularities of investment arbitration. 
2.3 The arbitrator or the arbitrator's law has advised a party on the dispute, or provided an expert opinion. ${ }^{1171}$

2.4 The arbitrator or the arbitrator's law firm had a prior involvement in the dispute. ${ }^{1172}$

2.5 The arbitrator's law firm is currently acting adversely to a party or its affiliate. ${ }^{1173}$

2.6 The arbitrator currently represents or advises the lawyer or law firm acting as counsel for one of the parties. ${ }^{1174}$

2.7 The arbitrator serves as a counsel in a concurrent proceeding, in which one of the counsel to a party in the present dispute serves as an arbitrator.

2.8 The arbitrator serves as a counsel in a concurrent proceeding, in which the same specific legal questions are determinative.

\section{Incompatible appointments to arbitral tribunals}

3.1 The same party (or its affiliate), the same counsel or the same law firm have appointed the arbitrator in a proceeding concerning the same or highly similar factual circumstances and / or the same or highly similar specific legal questions, within the past three years. ${ }^{1175}$

3.2 The arbitrator has previously served as an arbitrator in a proceeding involving one of the parties, and has as such co-authored an award to the detriment of said party, which was annulled within the last three years.

3.3 The arbitrator has previously served as an arbitrator in a proceeding, and has as such co-authored an award concerning the same factual circumstances and / or the same specific legal questions, which was annulled within the last three years.

\section{Disqualifying behavior}

4.1 The arbitrator has unnecessarily and harshly admonished counsel for one of the parties. ${ }^{1176}$

4.2 The arbitrator has publicly advocated a position on the case, whether in a published paper, or speech, or otherwise. ${ }^{1177}$

\footnotetext{
1171 ІвA Guidelines, Application Lists, § 2.1.1.

1172 ІвA Guidelines, Application Lists, $\S \S 2.1 .2$ and 2.3.5. General consensus in all dispute resolution mechanisms examined in Chapter 2.

1173 IBA Guidelines, Application Lists, § 3.4.1 and Blue Bank, expanded to reflect the particularities of investment arbitration.

1174 IBA Guidelines, Application Lists, § 2.3.2.

1175 Caratube reasonably expanded.

1176 Burlington.

1177 IBA Guidelines, Application Lists, § 3.5.2.
} 


\section{B Potential Grounds for Disqualification}

The following situations should be presumed to raise justifiable doubts as to an arbitrator's independence and impartiality, and should lead to a disqualification, unless the arbitrator can dispel such doubts:

1.1 The arbitrator has, within the past three years, been appointed as arbitrator on two or more occasions by one of the parties (or an affiliate of one of the parties), by the same counsel, or by the same law firm individually or collectively.1178

1.2 The arbitrator has, within the past three years, served as an arbitrator in two or more proceedings directed against the same State, and these appointments make up for a significant part of the arbitrator's overall appointments. ${ }^{1179}$

1.3 The arbitrator has within the past three years served as counsel for a party or its affiliate, or has previously advised or been consulted by a party or its affiliate in an unrelated matter, but the relationship is not ongoing. ${ }^{1180}$

1.4 By means other than academic publications, the arbitrator has publicly expressed his or her views on questions which are relevant in the current dispute.

1.5 The arbitrator and a counsel or law firm involved in the proceeding have, within the past three years, acted as co-counsel in more than three proceedings. ${ }^{1181}$

1.6 A lawyer in the arbitrator's law firm is an arbitrator or counsel in another dispute involving the same party or parties, or an affiliate of one of the parties. ${ }^{1182}$

The following situations may raise justifiable doubts as to the arbitrator's independence and impartiality. A case-by-case assessment should be made on a precautionary basis:

1178 IBA Guidelines, Application Lists, $\S \S 3.1 .3$ and 3.3.8, modified to reflect the particularities of investment arbitration.

1179 ІвА Guidelines, Application Lists, $\S 3.1 .5$, modified to reflect the particularities of investment arbitration.

1180 IBA Guidelines, Application Lists, § 3.1.1, modified to reflect the particularities of investment arbitration.

1181 IBA Guidelines, Application Lists, $\S 3.3 .9$, modified to reflect the particularities of investment arbitration.

1182 IBA Guidelines, Application Lists, § 3.3.4, modified to reflect the particularities of investment arbitration. 
2.1 The arbitrator has, within the past three years, served as a counsel in a proceeding, in which a counsel in the present proceeding served as an arbitrator.

2.2 The arbitrator has, in a previous proceeding, dealt with a legal question which could be determinative in the arbitration, and has issued a dissenting opinion.

2.3 The arbitrator has within the past three years served as counsel against a party or its affiliate in an unrelated matter. ${ }^{1183}$

2.4 The arbitrator's law firm has, within the past three years, acted for or against a party or its affiliate, in an unrelated matter without the involvement of the arbitrator. ${ }^{1184}$

2.5 The arbitrator has previously expressed a legal opinion concerning a specific legal issue which arises in the arbitration in an academic publication.

2.6 The arbitrator and a counsel have co-authored academic publications within the past three years.

2.7 The arbitrator has, in his previous role as a public servant, regularly dealt with the legal issues which arise in the arbitration.

C

\section{Unproblematic Circumstances}

Absent exceptional circumstances, the following situations should be considered not to raise justifiable doubts as to an arbitrator's independence and impartiality, and should not lead to a disqualification:

1. The arbitrator and a counsel for one of the parties are acquainted.

2. The arbitrator has previously expressed an opinion concerning a general legal or political issue arising in the arbitration in an academic publication or in a public speech. ${ }^{1185}$

3. A firm, in association or in alliance with the arbitrator's law firm, but that does not share significant fees or other revenues with the arbitrator's law

1183 IBA Guidelines, Application Lists, $§$ 3.1.2.

1184 IBA Guidelines, Application Lists, $§$ 3.1.4. The attorney-client relationship of a law firm which the arbitrator has only recently left should be considered under this category, and be treated the same if the modalities of the arbitrator's resignation from the law firm and his former position in the law firm reasonably create the impression that the arbitrator's continuing bond of loyalty towards the firm interferes with his dispassionate, objective and rational analysis of the case. In particular, if the arbitrator has been a partner within the firm, the firm's attorney-client relationships shall be imputed to the arbitrator during a phase-out period of three years ( $c f$. IBA Guidelines, Application Lists, $\S$ 3.3.3).

1185 IBA Guidelines, Application Lists, $§$ 4.1.1, modified to reflect the particularities of investment arbitration. 
firm, renders services to one of the parties, or an affiliate of one of the parties, in an unrelated matter. ${ }^{1186}$

4. The arbitrator has a relationship with another arbitrator, or with the counsel for one of the parties, through membership in the same professional association, or social or charitable organization, or through a social media network. ${ }^{1187}$

5. The arbitrator and counsel for one of the parties have previously served together as arbitrators. ${ }^{1188}$

6. The arbitrator teaches in the same faculty or school as another arbitrator or counsel to one of the parties, or serves as an officer of a professional association or social or charitable organization with another arbitrator or counsel for one of the parties. ${ }^{1189}$

7. The arbitrator was a speaker, moderator or organizer in one or more conferences, or participated in seminars or working parties of a professional, social or charitable organization, with another arbitrator or counsel to the parties. ${ }^{1190}$

8. The arbitrator has had an initial contact with a party, or an affiliate of a party (or their counsel) prior to appointment, if this contact is limited to the arbitrator's availability and qualifications to serve, or to the names of possible candidates for a chairperson, and did not address the merits or procedural aspects of the dispute, other than to provide the arbitrator with a basic understanding of the case. ${ }^{1191}$

9. The arbitrator has, in a previous proceeding, dealt with a legal question which could be determinative in the arbitration. ${ }^{1192}$

\section{Implementation of Suggested Reforms}

As far-reaching as the presented improvement suggestions will appear to some, they are considerably more conservative and mindful of the established

\footnotetext{
1186 IBA Guidelines, Application Lists, § 4.2.1.

1187 IBA Guidelines, Application Lists, § 4.3.1.

1188 IBA Guidelines, Application Lists, § 4.3.2.

1189 IBA Guidelines, Application Lists, § 4.3.3.

1190 IBA Guidelines, Application Lists, § 4.3.4.

1191 IBA Guidelines, Application Lists, § 4.4.1.

1192 See DAELE, supra note 51, If 6-191 ("[B]ecause in investment arbitration there is always overlap, the system would become unviable if this would constitute a ground for challenge.").
} 
investment arbitration system than other reform proposals which have been made. Their implementation also appears more realistic.

The ICSID-specific guidelines on conflicts of interest (Chapter 5, Part 2.4) suggested above could be realized without a revision of the ICSID Convention, and without interpretive statements to the Convention:1193 BIT parties could incorporate such guidelines into addendums to their BITS or IIAS whenever they are renewed. ${ }^{1194}$ This would allow for a comprehensive regulation of the matter, and for the relatively easy amendment of such guidelines, without a need for the re-negotiation of the entire IIA. ${ }^{1195}$

The proposed institutional reforms (Chapter 5 , Part 1), on the other hand, would require a revision of the ICSID Convention and Arbitration Rules. ${ }^{1196}$ In particular, Chapter 1, Section 2 ICSID Convention would have to be amended to provide for an Appointment and Confirmation Committee established by the Administrative Council. The respective provision would have to list the competencies of the Committee, namely the nomination of arbitrators to the Panel of Chairmen, the confirmation of party-appointed arbitrators, and the Committee's jurisdiction on arbitrator challenges. Chapter 1, Section 4 ICSID Convention would need to be supplemented by an additional article on the Panel of Chairmen, setting out the number of members on the panel and their service terms, as well as the required qualities and the nomination of the candidates by the Appointment and Confirmation Committee. An article on the confirmation of party-appointed arbitrators by the Appointment and Confirmation Committee would have to be added to Chapter 4, Section 2 ICSID Convention. Finally, Chapter 5 ICsID Convention would have to be revised to reflect the requirement of the Appointment and Confirmation Committee's confirmation of party-appointed arbitrators, and its jurisdiction on arbitrator challenges. This would require changes to Articles 57 and 58. The ICsID Arbitration Rules would also have to be revised to reflect the suggested reforms.

Article 57 ICSID Convention does not need to be revised to allow for the application of a justifiable doubts standard, since this interpretation corresponds with the legislative history and the regulatory purpose of the ICSID

1193 See Horvath and Berzero, supra note 37, at 16 (suggesting that the prohibition of dual roles could be provided for in interpretive statements according to Vienna Convention art. 31, para. 3 (a) and (b)); Bernasconi-Osterwalder, Johnson, and Marshall, supra note 32, at 6 .

1194 Bernasconi-Osterwalder, Johnson, and Marshall, supra note 32, at 6.

1195 Horvath and Berzero, supra note 37 , at 18.

1196 The disputing parties' agreement on an institutional jurisdiction for arbitrator challenges, for example, would appear not to be binding without a revision of ICSID Convention art. $5^{8}$ (cf. Kinnear and Nitschke, supra note 13, at 47.). 
Convention. ${ }^{1197}$ For the sake of legal certainty and in light of the comprehensive amendments required in the context of institutional reforms (including a revision of Article 57), it would however be advisable to explicitly clarify the challenge threshold in Article 57, by amending its wording as follows:

A party may propose to the Appointment and Confirmation Committee the disqualification of any member of a tribunal or of an ad hoc Committee on account of any fact which from the perspective of a reasonable third person raises justifiable doubts as to the qualities required by paragraph (1) of Article 14. A party to arbitration proceedings may, in addition, propose the disqualification of an arbitrator on the ground that he was ineligible for appointment to the Tribunal under Section 2 of Chapter IV.

Resistance against the presented reform proposals and difficult negotiations on the exact amendments of the ICSID Convention are inevitable. However, it appears more realistic that the ICSID Contracting States would agree on conservative amendments of the ICSID Convention and Arbitration Rules, rather than the abolishment of party-appointments, a prohibition of dual functions, or the delegation of the settlement of investment disputes to permanent international tribunals. If the legitimacy of the ICSID system is to be preserved, and the loss of confidence in its arbitrators halted, the proposed suggestions are the least intrusive, and most effective alternative to more fundamental reform proposals.

1197 See supra Chapter 1, Part 1.2; DAELE, supra note 51, \ 5-035. 